\title{
Seed dispersal by vertebrates in Madagascar's forests: review and future directions
}

\author{
Onja H. Razafindratsima
}

\author{
Rice University \\ Houston, TX, USA. \\ E-mail: onja@rice.edu
}

\begin{abstract}
Madagascar's highly diverse forests are critically threatened because of increasing deforestation, and those that remain are facing declines of vertebrate frugivores that disperse their seeds. Thus, understanding plant-frugivore interactions is of critical importance for the conservation and maintenance of plant diversity in Madagascar. This paper reviews observational and experimental studies of the multifaceted aspects of seed dispersal by vertebrates across Madagascar including the relative importance of different seed vectors, the patterns of seed deposition, and the post-dispersal fate of dispersed seeds. This also aims to lay a foundation for future studies by discussing understudied aspects that are crucial for the understanding of the role of frugivores on plant populations and communities in Malagasy forests. Such perspectives are important given the increasing threats to seed dispersers, the low richness of frugivore assemblages in Malagasy forests and the strong reliance of many plant species on frugivores for their dispersal. Understanding this ecosystem service can provide us insights on plant colonization, community structure, demography and invasion, as well as forest restoration and regeneration.
\end{abstract}

\section{RÉSUMÉ}

Les forêts de Madagascar abritent des communautés de plantes vasculaires exceptionnellement diverses avec un taux d'endémisme s'élevant à $82 \%$. Malheureusement, hormis les continuelles dégradation et fragmentation menaçant ces forêts, la flore malgache est aussi menacée par l'insuffisance et le déclin des populations d'animaux frugivores qui jouent un rôle fondamental dans la dissémination des graines. La compréhension de ce mécanisme de dissémination des graines par des frugivores est importante pour savoir comment préserver la biodiversité et la régénération forestière ainsi que pour établir des stratégies de conservation des habitats fragmentés. Le présent article constitue une synthèse des publications scientifiques sur les recherches concernant ce mécanisme dans les forêts malgaches. Les informations disponibles sont plutôt limitées mais suggèrent que la majorité des plantes malgaches dépendent des vertébrés frugivores pour la dissémination de leurs graines. Ces études montrent également quelques aspects portant sur des modèles de dispersion des graines et des plantules. Plusieurs éléments relatifs à ce mécanisme sont encore inconnus et nécessitent des recherches approfondies.
Les pressions menaçant les différents vecteurs de graines sont discutées, et plus particulièrement celles qui pourraient avoir des effets néfastes sur la démographie des populations de plantes. En outre, des recommandations sont formulées pour permettre l'intégration des interactions frugivore-plante dans la conservation des écosystèmes forestiers malgaches.

\section{INTRODUCTION}

Madagascar's forests hold exceptionally diverse vascular plant communities with up to $82 \%$ endemism (Callmander et al. 2011). The increasing threats of habitat destruction and fragmentation facing these forests are well known (Ganzhorn et al. 2001, Harper et al. 2007, Watson et al. 2010, Allnutt et al. 2013); however, another looming threat to Madagascar's flora has recently become apparent: the lack and decline of important seed dispersers such as frugivorous vertebrates. This is critical because Malagasy forests have already depauperate frugivore communities (Langrand 1990, Hawkins and Goodman 2003), which are also currently threatened by the increasing anthropogenic disturbances and climate change (Dunham et al. 2008, Barrett and Ratsimbazafy 2009, Dunham et al. 2011, Dewar and Richard 2012, Ratsimbazafy et al. 2013, Schwitzer et al. 2013). Thus, examining vertebrate-mediated seed dispersal in this system is crucial for understanding the maintenance of plant diversity and for the conservation of the diverse plant communities in Madagascar, which supports one of the world's hottest hotspots of biodiversity (Ganzhorn et al. 2001).

There has been no synthesis about our current knowledge of this ecosystem service in Madagascar. Understanding seed dispersal is important because of the fundamental role of this mechanism in plant colonization, community structure, demography and invasion, and in forest regeneration (Howe and Smallwood 1982, Terborgh et al. 2002, Ibáñez et al. 2006, Schupp et al. 2010, Jordano et al. 2011). Seed dispersal studies have also a central place in conservation, natural restoration of degraded habitats and ecosystem functioning (Farwig and Berens 2012).

In this paper, I synthesize published literature of studies on seed dispersal by frugivorous vertebrates in Malagasy forests to establish a foundation for future studies to understand the importance of frugivores for plant populations. Specifically, I address the following questions in reference to Malagasy forests: i) What is known about seed removal from parent plants? ii) Where are seeds dispersed? and iii) What are the consequences 


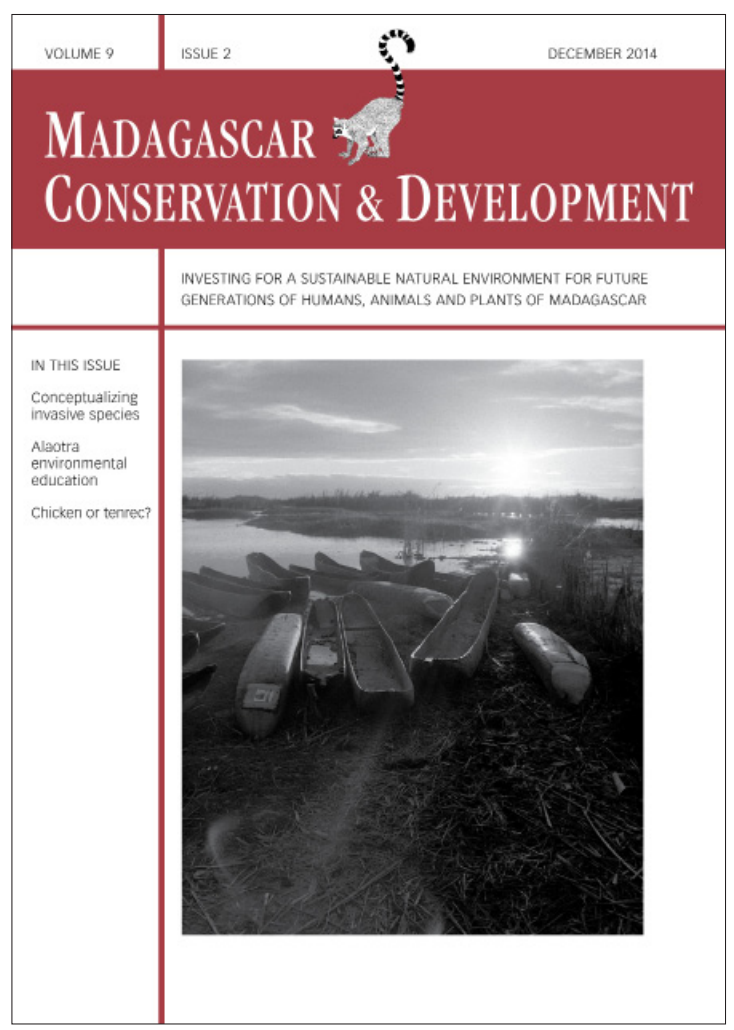

Madagascar Conservation \& Development is the journal of Indian Ocean e-Ink. It is produced under the responsibility of this institution. The views expressed in contributions to MCD are solely those of the authors and not those of the journal editors or the publisher.

All the Issues and articles are freely available at http://www.journalmcd.com

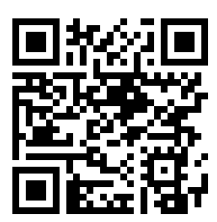

Contact Journal MCD

info@journalmcd.net for general inquiries regarding MCD funding@journalmcd.net to support the journal

Madagascar Conservation \& Development Institute and Museum of Anthropology University of Zurich

Winterthurerstrasse 190

$\mathrm{CH}-8057$ Zurich

Switzerland

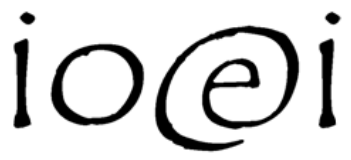

Indian Ocean e-Ink

Promoting African Publishing and Education

www.ioeink.com

Missouri Botanical Garden (MBG)

니는 Missouri Botanical Garden Madagascar Research and Conservation Program BP 3391

Antananarivo, 101, Madagascar 
of dispersal on seed fate? I also review the threats that frugivores are facing, and the potential impacts of the absence of frugivores for Malagasy forests. Further, I discuss research areas that are particularly important for future directions of study that may help us integrate seed dispersal interactions in conservation management in Madagascar's forests.

\section{SYNTHESIS OF SEED DISPERSAL RESEARCH IN MADAGASCAR'S FORESTS}

SEED REMOVAL FROM PARENT PLANTS. Fruit traits are

important in determining potential dispersal agents, as they are hypothesized to evolve under the selective pressures of seed vectors such that unrelated plant species sharing seed dispersers may have similar traits (Lomáscolo and Schaefer 2010). Such traits include fruit morphology, color, size, presence of edible pulp, presence of wings or any external modifications, husk thickness and weight (Howe and Smallwood 1982). Particularly, in vertebrate-dispersed plant species, traits such as color, size, fruit protection and nutrient reward play an important role in the attraction of seed dispersers (Schaefer et al. 2004, Bollen 2007), and usually match the behavior and physiology of different disperser taxa (Lomáscolo et al. 2010). For example, recent work by Valenta et al. (2013) demonstrates that fruit color and odor predict the selection of fruits in nocturnal mouse lemurs (Microcebus spp.), which have dichromatic color vision; fruits dispersed by these species showed greater color contrast from leaves under moonlight conditions than non-dispersed fruits. Overall, a majority of plant species in Malagasy forests have fruit traits that suggest adaptation for seed dispersal by frugivorous vertebrates (Scharfe and Schlund 1996, Birkinshaw 2001, Bollen et al. 2004a, Bollen et al. 2005), especially by primates. In the littoral forest of Sainte Luce, for instance, a majority of tree species, especially large-seeded ones, critically depend on Eulemur (fulvus) collaris for seed dispersal, although specific fruit traits were not tightly correlated with specific groups of frugivores (Bollen et al. 2004a). In addition, morphological and chemical analyses of fruit traits supported a predominance of primatedispersed species in a Malagasy tree community compared to a similar tree community in South Africa (Voigt et al. 2004).

Large- and small-sized lemurs are often reported as the main frugivores and primary seed dispersers in Madagascar's forests; however, studies of seed dispersal by bats and birds have been limited (Supplementary Material). In addition to the important quantity of ripe fruits in their diet, they are able to defecate intact and viable large- and small-sized seeds, which can enhance seed germination and seedling growth (Dew and Wright 1998, Razafindratsima and Razafimahatratra 2010, Moses and Semple 2011, Razafindratsima and Martinez 2012, Sato 2012). For example, Varecia variegata in the southeastern Manombo rainforest passed the seeds of 40 different plant species during a 3-month study period, and the lemur-passed seeds had higher germination success than non-passed seeds (Moses and Semple 2011). It is, however, possible that not all frugivorous lemurs have positive dispersal effects on their feeding plants. For instance, a behavioral comparison among sympatric lemurs suggests that Propithecus spp., which spend up to $48 \%$ of their feeding time on fruits (Overdorff and Strait 1998), are mainly seed predators. They consume both ripe and unripe fruits, masticating seeds while feeding or dropping seed pieces under the parent trees, and digesting those that they swallowed (Ralisoamalala 1996, Dew and Wright 1998, Overdorff and Strait 1998, Böhning-Gaese et al. 1999). Also, the effectiveness of dispersal has been observed to vary across lemur species (Overdorff and Strait 1998, Razafindratsima et al. 2014). For example, Varecia variegata editorum in the southeastern rainforest of Ranomafana National Park were observed to perform long-distance seed dispersal compared to its sympatric Eulemur spp. (Razafindratsima et al. 2014).

Besides primates, birds are also recognized as one of the major groups of seed dispersers in tropical ecosystems (Fleming 1979, Herrera 2002). Madagascar has a relatively low richness of bird species compared to other tropical regions (Kissling et al. 2012); and only about $10 \%$ of bird species in Madagascar are known to consume fruits (del Hoyo et al. 1992). However, the limited number of studies on seed-dispersal by birds in Madagascar demonstrates that some frugivorous birds may act as effective seed dispersers. While their diversity is low relative to other tropical forests, their high abundances may make them important dispersers in the system, and particularly given the current decline of frugivorous lemurs. Six of the known frugivorous bird species were observed to swallow and disperse the seeds of several small-seeded plant species across Madagascar (Supplementary Material), especially understory shrubs (Rakotomanana et al. 2003). For instance, Philepitta castanea in the rainforest of Ranomafana are estimated to disperse $85.7 \%$ of ingested seeds away from the parent crowns (ibid). The Madagascar blue pigeon (Alectroenas madagascariensis), feeds on many of the same large-seeded fruits as large-bodied diurnal lemurs (pers. observ.), and is distributed across the entire eastern rainforest region. This species may carry out an important ecosystem service, particularly in areas where lemur populations are dwindling, though future studies are warranted. The two parrot species, Coracopsis nigra and C. vasa, appear to be mainly seed predators because they either peck at fruits and drop them under the parent tree, or destroy the majority of seeds they consume by splitting or digesting the seeds (Scharfe and Schlund 1996, Goodman et al. 1997, Bollen et al. 2004a, b). However, these parrots can also be opportunistic seed dispersers as they were occasionally observed carrying seeds in their beaks away from the parent crowns (Böhning-Gaese et al. 1995, Bleher and Böhning-Gaese 2001).

Some studies also suggest that frugivorous bats can act as important seed dispersers in Madagascar as they are swallowing and defecating the intact seeds of small-seeded plant species (Bollen and Van Elsacker 2002, Long and Racey 2007, Picot et al. 2007, Ratrimomanarivo 2007, Andrianaivoarivelo et al. 2011, Andrianaivoarivelo et al. 2012). Bats may also play important role in ensuring genetic exchange between forest fragments because they are able to travel long-distances from their roost for foraging (Bollen and Van Elsacker 2002, Andrianaivoarivelo et al. 2011). For example, fecal analyses by Picot et al. (2007) showed that seeds of trees located at least five kilometers from the roost were frequently recorded in the diet of the Malagasy fruit bat Eidolon dupreanum. Furthermore, the passage of seeds through the digestive tracts of bats appears to facilitate seed germination (Andrianaivoarivelo et al. 2011).

Other frugivorous vertebrate groups such as lizards, fish, tortoises and bush pigs can also be effective dispersers in tropical forests (Valido and Olesen 2007, Anderson et al. 2011, Blake et al. 2012), but studies of the seed-dispersal services by such 
groups in Malagasy ecosystems are limited. Three frugivorous reptilian species (Oplurus cuvieri, Pyxis planicauda and Zonosaurus laticaudatus) are listed as potential seed dispersers in the western dry forest of Kirindy (Ganzhorn et al. 1999). Work exploring the role of reptiles is an important area of research in this area, particularly in the arid habitats of Madagascar. Pedrono et al. (2013) report that the two extinct species of Malagasy giant tortoises (Aldabrachelys grandidieri and A. abrupta) may have played the role of seed dispersers for large-sized seeds as their close relative Aldabrachelys gigantea are effective seed dispersers on Aldabra atoll.

SEED DEPOSITION. Removal of seeds away from parent

plants is not enough to assess the quality and effectiveness of different dispersal vectors because the patterns of seed deposition can influence plant recruitment (Schupp et al. 2010, Wang and Smith 2002). Three aspects are often discussed as crucial in determining the consequences of seed dispersal on plant reproductive success: the distances of dispersed seeds from parent and conspecific adult trees, the microsites (i.e., local environment) where seeds land, and the aggregation patterns of seed dispersion (Muller-Landau and Hardesty 2005).

The distance of a seed from its parent tree can strongly influence its recruitment because it allows the seeds to escape density-dependent mortality resulting from species-specific natural enemies, and reduces sibling competition near parent and conspecific adult-trees (Janzen 1970, Connell 1971, Hubbell 1979). Although limited, studies of seed-dispersal distances in Madagascar have provided useful information regarding the patterns of seed dispersal in Malagasy forests, and the effectiveness of some dispersal groups. Using data on gut-passage times, movement patterns and home ranges, which can often be used to predict dispersal distance in vertebrate-dispersed plants (Muller-Landau and Hardesty 2005), studies have reported short average dispersal distance $(83-180 \mathrm{~m})$ for tree species that are dispersed by large-bodied lemur species (Moses and Semple 2011, Martinez and Razafindratsima 2014, Razafindratsima et al. 2014), which may be due to their relatively small home-range sizes and day-range lengths (Razafindratsima et al. 2014). Bleher and Böhning-Gaese $(2000,2001)$ also reported that a bird-dispersed tree, Commiphora guillauminii, in the western dry forest of Kirindy had shorter dispersal distances than its congener in South Africa, affecting seedling establishment (i.e., independent growth of emerging seedlings) and spatial distribution. This short-dispersal pattern of Commiphora resulted in high genetic differentiation of trees at a local spatial scale (Voigt et al. 2009). Malagasy fruit bats may be able to perform long-distance seed dispersal (> $500 \mathrm{~m}$ ) because they can travel relatively far from their roost to feed (Bollen and Van Elsacker 2002, Picot et al. 2007), but empirical studies are lacking. Long seed-dispersal distances were rarely observed for lemur-dispersed trees. However, such long-distance dispersal events, even rare, may be important because they can facilitate the colonization of new habitat and increase gene flow between and within populations (Cain et al. 2000). For instance, a genetic study of the spread of Beccariophoenix madagascariensis, which is a palm species with lemur-dispersed fruits in eastern Malagasy forest, suggest that long-distance seed dispersal may have contributed to the significant gene flow observed between populations that are within three kilometers of each other (Shapcott et al. 2007).
The microsites, in which seeds land after removal from their parent plants, can also influence their germination and survivorship, the probability of seedling establishment and survival, and subsequent recruitment success (Howe and Smallwood 1982, Muller-Landau and Hardesty 2005, Beckman and Rogers 2013). Thus, a critical step in understanding the effectiveness of frugivores as seed dispersers is to examine how biotic and abiotic factors associated with the microsites, where frugivores disperse seeds, affect seed fate. Work addressing such question in Madagascar is limited, but would contribute greatly to our understanding of the impacts of frugivores on the demography of plant populations. For example, a recent study by Razafindratsima and Dunham (2014) in Ranomafana National Park demonstrates that seeds of Cryptocarya crassifolia dispersed by three frugivorous lemurs into gap habitat ( $<55 \%$ canopy cover) had higher recruitment probability than those dispersed under more closed canopies.

The degree and scale of seed aggregations are also crucial for plant recruitment success; for example, high clumping of seeds may result in high density-dependent seed mortality because it increases resource competition among siblings and attracts seed-predators (Schupp et al. 2002, MullerLandau and Hardesty 2005). Clumping can also be beneficial for plants because it can reduce interspecific competition (Muller-Landau and Hardesty 2005), and increase disperser attraction for subsequent dispersal as a result of clumped distribution of trees that share seed dispersers (Clark et al. 2004). In general, low clumping is expected for wind-dispersed species (Muller-Landau and Hardesty 2005), but seed dispersal by animals is likely to result in high clumping (Schupp et al. 2002). These patterns may vary by animal taxa and by dispersal systems (Clark et al. 2004). In Malagasy systems, the seeds of bat-dispersed plant species were often disproportionately deposited near roost trees (Picot et al. 2007), but we do not know whether such microsites are favorable for seedling establishment. There is also a paucity of published research detailing the spatial distribution of seed dispersal in Madagascar forests; the understanding of such aspect could provide us better insights on the role of frugivores in structuring plant communities.

These three attributes of seed deposition patterns are expected to increase the odds of recruitment success for individual seeds and may therefore affect plant demography (Howe and Smallwood 1982). For instance, nonrandom seed dispersal by three frugivorous lemurs in Ranomafana rainforest increased per-seed sapling recruitment by four fold compared to no dispersal (i.e., seeds simply falling under parent trees) (Razafindratsima and Dunham 2014). Also, the spatial distribution of Commiphora guillauminii seedlings (bird-dispersed tree species) in the western dry forest of Kirindy (BöhningGaese et al. 1999), and of a lemur-dispersed tamarind species (Tamarindus indica) in southern dry forest of Berenty (MertlMillhollen et al. 2011) revealed a significantly higher probability of seedling establishment away from the parent trees than beneath the parent crowns. These dynamics may differ by plant species that experience different environmental conditions, and much research is needed to understand how plant demographic patterns as well as how plant populations might be affected by the absence of dispersers. 
POST-DISPERSAL SEED FATE AND PLANT RECRUITMENT

SUCCESS. After dispersal, seeds experience a number of factors that influence their germination and recruitment (e.g., predation, disease, and nutrient availability). Frugivore dispersers can influence germination as a result of removal of pulp or husks (which removes germination inhibitors), scarification of seeds, and fertilization with fecal matter (cf. Traveset et al. 2007 for review). There are mixed results from manipulative experiments (in laboratory and nursery) examining the germination of seeds that passed through the guts of Malagasy frugivores compared with non-passed seeds. Seeds passed through the guts of some lemur species had higher germination success than seeds that were manually extracted from fruits (Dew and Wright 1998 Razafindratsima and Razafimahatratra 2010, Moses and Semple 2011, Razafindratsima and Martinez 2012, Sato 2012). The same beneficial effects on the germination of their dispersed seeds are also observed in the fruit bat Eidolon dupreanum (Picot et al. 2007). However, seeds passed through the guts of the velvet asity Philepitta castanea (Rakotomanana et al. 2003) had less successful germination than non-passed seeds. There was no effect of gut-passage on the germination of seeds for those passed by Eulemur rufifrons (cited as E. fulvus) at the dry forest of Kirindy (Scharfe and Schlund 1996), and the fruit bat Pteropus rufus in the littoral forest of Sainte Luce (Bollen and Van Elsacker 2002). Also, Overdorff and Strait (1998) found that none of the five plant species passed by Eulemur rufifrons of the rainforest of Ranomafana in the early dry season germinated, whereas Dew and Wright (1998) reported a high proportion of germination for seeds passed by this species in the late dry season. Passage of seeds through guts can also reduce seed predation. For instance, seeds of the genus Grewia defecated by Eulemur rufifrons (cited as E. rufus) in the dry forest of Kirindy were neither preyed on by predators nor removed by secondary dispersers while non-defecated seeds were destroyed by insects and secondarily dispersed by ants (Spehn and Ganzhorn 2000).

Dispersed seeds may also be susceptible to subsequent movement by secondary seed dispersers (e.g., ants, rodents and dung beetles) or by other means (e.g., runoff). Secondary dispersal often significantly changes the patterns of seed deposition, and thus affects plant recruitment success (Vander Wall et al. 2005). For example, secondarily dispersed seeds buried by dung beetles may have a higher seedling establishment than non-removed seeds (Andresen 2001). Scatter-hoarding rodents can also reduce seed spatial clumping as they remove individual seeds into their caches, which may be far from the seed source (Wang and Smith 2002). There are few studies that quantified the rates and effects of secondary dispersal in Malagasy forests, mainly by ants and rodents. In an ant-foraging experiment in Kirindy forest, Böhning-Gaese et al. (1999) observed that Aphaenogaster swammerdami increased seed clumping by depositing secondarily removed seeds in piles at the edge of the colony, while Pheidole sp. carried seeds into their colony. Also, secondary dispersal by these ant species increased the establishment success of plants, but at a lower magnitude than the activity of primary dispersers. In addition, Voigt et al. (2002) found higher rates of secondary dispersal by ants of Commiphora seeds in a Malagasy site compared to a South African site. As for secondary dispersal by rodents, a predator exclosure experiment by Dausmann et al. (2008) showed that up to $100 \%$ of the seeds were removed within seven days, mainly by native rodents. In addition, work by Goodman and Sterling (1996) showed that native Malagasy rodents cache seeds in their burrows, but the effects of caching on seed viability were not quantified. Studies of secondary dispersal can provide us better insights on the pattern of diversity and persistence of some plant species, especially those adapted for dispersal by extinct large-sized frugivores (Jansen et al. 2012). Much research is needed on this aspect in Malagasy forests.

EXTINCT SEED DISPERSERS AND THREATS TO SEED

DISPERSAL. Seed dispersal of Malagasy plants may be restricted due to the low diversity of available and effective dispersers, and may be at risk because of the pressures threatening disperser communities. Madagascar's forests have already lost at least 34 large-sized endemic vertebrates, and the extant communities are vulnerable to anthropogenic and climate pressures (Pedrono et al. 2013). The extinct megafauna could have been effective seed dispersers of many native plant species in Madagascar, especially large-seeded species (Crowley et al. 2011, Pedrono et al. 2013). Reconstruction and inference of diet in extinct lemur species demonstrate that most of them were consuming fruits (Godfrey et al. 1997) and were most likely the main primary seed dispersers of large-seeded native trees (Crowley et al. 2013). Also, the extinct large-bodied flightless bird of the genus Aepyornis could have been the main seed dispersers of the spiny fruits of Uncarina (Midgley and Illing 2009). This endemic plant species has mature fruits with large grapple hooks not adapted for consumption by extant Malagasy vertebrates, but the hooks may adhere to the bird's feet when mature fruits fall on ground (Midgley and Illing 2009). Extinct giant tortoises may have also been important seed dispersers in Madagascar. The Aldabra giant tortoise, currently found on the Aldabra Atoll (400 km north of Madagascar) is thought to be the same, or a subspecies of a giant tortoise now extinct in Madagascar. Hnatiuk (1978) reported that this species has a long gut-retention time and may have been responsible for the introduction of several Malagasy plant species on Aldabra Atoll as a result of transmarine migration from Madagascar. Thus, they may have been active seed dispersers when they inhabited Madagascar as well. A feeding experiment was recently done by Andriantsaralaza et al. (2014), in which Aldabra giant tortoises at Tsimbazaza zoo in Antananarivo, were fed with the fruits of a Malagasy endemic baobab species, which is thought to have no extant seed dispersers. Results supported that this extinct species could have played important role as seed dispersers of this large-seeded plant species by defecating intact and viable seeds.

The decline or loss of dispersers in a community may alter seed dispersal mechanism and subsequent recruitment dynamics (e.g., Cordeiro and Howe 2003) leading to changes in plant community structure. In Madagascar, studies examining the impacts of the absence of dispersers on plant communities are limited. Work by Ganzhorn et al. (1999) in the dry forest of Kirindy shows that forest fragments without Eulemur rufifrons had fewer lemur-dispersed trees regenerating than fragments with lemurs, suggesting that forest regeneration in Kirindy depends on the presence of lemur dispersers. With a low diversity of frugivores and a lack of effective dispersers in certain areas (Bleher and Böhning-Gaese 2000), seed dispersal in Madagascar may be at risk, and Malagasy plant communities may be especially susceptible to failures in recruitment and/or regeneration. Moreover, the disappearance of large frugivores 
in Malagasy ecosystems could also mean that plants formerly dispersed by megafauna in Madagascar, including large-seeded and seeds with thick husks, are at risk of dispersal limitation with low recruitment success.

\section{CONCLUDING REMARKS AND FUTURE DIRECTIONS}

As seed dispersal is crucial for the maintenance of natural forest ecosystems, conservation approaches should consider prioritizing the protection of both plant and animal species involved in this mechanism, and the management of 'high-quality habitats' that are favorable for seedling establishment at the communitylevel (Farwig and Berens 2012). Approaches for the restoration of degraded and fragmented forests should also incorporate seed dispersal interactions. For example, the restoration of forest fragments in Masoala National Park by the Wildlife Conservation Society, which aimed in attracting seed dispersers to bring forest seed species into the fragments (Holloway 2000), was successful in that regard as Varecia rubra were observed depositing seeds in the regenerating forests (Martinez and Razafindratsima 2014). Increasing connectivity of forest fragments via corridors may also encourage the movement of dispersers between fragments and thus enhance their regeneration.

Previous work on seed dispersal in Madagascar has contributed greatly to our understanding of the roles of frugivores as seed dispersers in Madagascar's forests. However, more research is still needed. An important future direction for understanding the importance of frugivore-mediated seed dispersal is to address questions related to the ability of dispersers to replace each other in Malagasy forests given that ecosystem resilience can be mitigated if the extinction of one species could be offset by other species with equivalent ecological services (Walker 1995). Recent work by Pedrono et al. (2013) suggests that the introduction of frugivorous tortoises that are closely related to the extinct Malagasy giant tortoises could help in the restoration of the dispersal of large-seeded species that currently have no known effective dispersers. A similar introduction project of the Aldabra giant tortoises to replace extinct tortoise species on the Mascarene island of Rodrigues has proven success restoring seed dispersal and removing exotic vegetation on the island (ibid).

Work addressing questions related to the disruption of plant-disperser interactions in Madagascar would also lead to a better understanding of the importance of seed dispersal in maintaining plant diversity in Malagasy forests. The long- and short-term impacts of low diversity of seed dispersers on plant communities have rarely been studied, and the repercussions are still unclear (but cf. Bleher and Böhning-Gaese 2000, 2001); however it has been suggested that the loss of frugivores from the ecosystem may have long-term impacts on future forest composition (cf. review in Farwig and Berens 2012).

Another important focus of future studies is to address questions related to understudied taxonomic and functional groups such as birds, nocturnal species, secondary dispersers and granivores (i.e., seed-eating animals). Granivores, such as rodents, are often considered as seed predators since they forage on and masticate ripe seeds; however they can be effective secondary seed dispersers (Forget and Cuijpers 2008), and could maintain the dispersal of large-seeded plant species as they presumably can fill-in partially the role of extinct megafauna as seed dispersers through scatter-hoarding of seeds (Jansen et al. 2012).
Future studies should also be expanded to other regions of Madagascar because the disperser communities we know so far were restricted to a small portion of the forested areas (Figure 1). In addition, long-term studies need to be established and maintained to examine temporal variations in seed dispersal mechanisms and the dynamics of plant recruitment to better improve our understanding of the effects of dispersers on plant populations. We also need to examine plant recruitment at the habitat-level because we cannot make implicit assumptions of disperser effectiveness based solely on their ability to remove seeds away from parent trees and deposit intact and viable seeds. There are abiotic factors and biotic interactions in the environment that could influence the establishment success of deposited seeds depending on where seeds land.

The future research outlined here would form a more comprehensive framework necessary to understand and conserve the critical ecosystem service of seed dispersal by vertebrates in Madagascar. Based on the few published studies, it is clear that the topic area is ripe for further exploration. There is also an urgent need for inter-disciplinary researchers to form collaborative networks to explore mechanisms underlying the patterns of plant diversity in Madagascar, and predict patterns of plant demography and forest dynamics relative to the loss of dispersers.

\section{ACKNOWLEDGEMENTS}

I would like to thank Maria Meza-Lopez and Drs. Amy Dunham, Barbara Martinez, Haldre Rogers and Scott Solomon, and two anonymous reviewers for their helpful comments and suggestions; Kelsey Devine for helping in data collection; and to Rice University and Schlumberger Foundation for financial support.

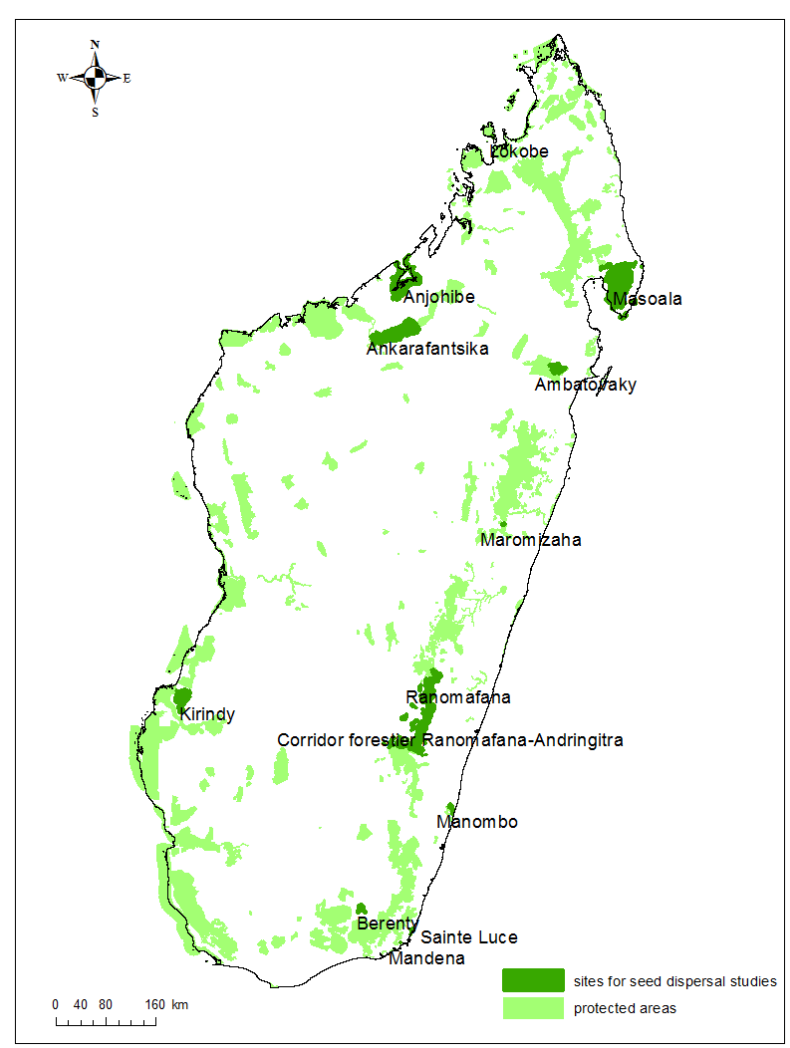

FIGURE 1. Location of sites in Madagascar where seed dispersal studies were conducted (shapefile source: REBIOMA project 2010). 


\section{REFERENCES}

Allnutt, T. F., Asner, G. P., Golden, C. D. and Powell, G. V. N. 2013. Mapping recent deforestation and forest disturbance in northeastern Madagascar. Tropical Conservation Science 6, 1: 1-15.

Anderson, J. T., Nuttle, T., Rojas, J. S. S., Pendergast, T. H. and Flecker, A. S. 2011. Extremely long-distance seed dispersal by an overfished Amazonian frugivore. Proceedings of the Royal Society B: Biological Sciences 278, 1723: 3329-3335. (doi:10.1098/rspb.2011.0155)

Andresen, E. 2001. Effects of dung presence, dung amount and secondary dispersal by dung beetles on the fate of Micropholis guyanensis (Sapotaceae) seeds in Central Amazonia. Journal of Tropical Ecology 17, 1: 61-78. (doi:10.1017/S0266467401001043)

Andrianaivoarivelo, R. A., Ramilijaona, O. R., Racey, P. A., Razafindrakoto, N. and Jenkins, R. K. B. 2011. Feeding ecology, habitat use and reproduction of Rousettus madagascariensis Grandidier, 1928 (Chiroptera: Pteropodidae) in eastern Madagascar. Mammalia 75, 1: 69-78. (doi:10.1515/mamm.2010.071)

Andrianaivoarivelo, R. A., Petit, E. J., Razafindrakoto, N. and Racey, P. A. 2012. Feeding preference and seed dispersion by Roussetus madagascariensis Grandidier 1928 in North-western Madagascar. Revue d'Ecologie, la Terre et la Vie 67: 179-191.

Andriantsaralaza, S., Pedrono, M., Tassin, J., Roger, E., Rakouth, B. and Danthu, P. 2014. The role of extinct giant tortoises in the germination of extant baobab Adansonia rubrostipa seeds in Madagascar. African Journal of Ecology 52, 2: 246-249. (doi:10.1111/aje.12101)

Barrett, M. A. and Ratsimbazafy, J. 2009. Luxury bushmeat trade threatens lemur conservation. Nature 461: 470. (doi:10.1038/461470a)

Beckman, N. G. and Rogers, H. S. 2013. Consequences of seed dispersal for plant recruitment in tropical forests: interactions within the seedscape. Biotropica 45, 6: 666-681. (doi:10.1111/btp.12071)

Birkinshaw, C. R. 1999. The importance of the black lemur (Eulemur macaco) for seed dispersal in Lokobe forest, Nosy Be. In: New Directions in Lemur Studies. B. Rakotosamimanana, H. Rasamimanana, J. U. Ganzhorn and S. M. Goodman (eds.), pp 189-199. Springer US.

Birkinshaw, C. R. 2001. Fruit characteristics of species dispersed by the black lemur (Eulemur macaco) in the Lokobe Forest, Madagascar. Biotropica 33, 3: 478-486. (doi:10.1111/j.1744-7429.2001.tb00201.x)

Blake, S., Wikelski, M., Cabrera, F., Guezou, A., Silva, M., et al. 2012. Seed dispersal by Galápagos tortoises. Journal of Biogeography 39, 11 1961-1972. (doi:10.1111/j.1365-2699.2011.02672.x)

Bleher, B. and Böhning-Gaese, K. 2000. Seed dispersal by birds in a South African and a Malagasy Commiphora species. Ecotropica 6, 1: 43-53.

Bleher, B. and Böhning-Gaese, K. 2001. Consequences of frugivore diversity for seed dispersal, seedling establishment and the spatial pattern of seedlings and trees. Oecologia 129, 3: 385-394. (doi:10.1007/ s004420100747)

Bodin, Ö., Tengö, M., Norman, A., Lundberg, J. and Elmqvist, T. 2006. The value of small size: loss of forest patches and ecological thresholds in southern Madagascar. Ecological Applications 16: 440-451. (doi:10.1890/1051-0761(2006)016[0440:TVOSSL]2.0.CO;2)

Böhning-Gaese, K., Gaese, B. H. and Rabemanantsoa, S. B. 1995. Seed dispersal by frugivorous tree visitors in Malagasy tree species Commiphora guillaumini. Ecotropica 1: 41-50.

Böhning-Gaese, K., Gaese, B. H. and Rabemanantsoa, S. B. 1999. Importance of primary and secondary seed dispersal in the Malagasy tree Commiphora guillaumini. Ecology 80: 821-832. (doi:10.1890/00129658(1999)080[0821:IOPASS]2.0.CO;2)

Bollen, A. 2007. Fruit characteristics: fruit selection, animal seed dispersal and conservation matters in the Sainte Luce forests. In: Biodiversity, Ecology, and Conservation of Littoral Ecosystems in the Region of Tolagnaro (Fort Dauphin), Southeastern Madagascar. J. U. Ganzhorn, S. M. Goodman and M. Vincelette (eds.), pp 127-145. Smithsonian Institution, Washington, DC

Bollen, A. and Van Elsacker, L. 2002. Feeding ecology of Pteropus rufus (Pteropodidae) in the littoral forest of Sainte Luce, SE Madagascar. Acta Chiropterologica 4, 1: 33-47. (doi:10.3161/001.004.0105)

Bollen, A. and Van Elsacker, L. 2004. The feeding ecology of the Lesser Vasa Parrot, Coracopsis nigra, in south-eastern Madagascar. Ostrich: Journal of African Ornithology 75, 3: 141-146. (doi:10.2989/00306520409485425)
Bollen, A., Van Elsacker, L. and Ganzhorn, J. U. 2004a. Tree dispersal strategies in the littoral forest of Sainte Luce (SE-Madagascar). Oecologia 139, 4: 604-616. (doi:10.1007/s00442-004-1544-0)

Bollen, A., Van Elsacker, L. and Ganzhorn, J. U. 2004b. Relations between fruits and disperser assemblages in a Malagasy littoral forest: a community-level approach. Journal of Tropical Ecology 20, 6: 599-612. (doi:10.1017/S0266467404001853)

Bollen, A., Donati, G., Fietz, J., Schwab, D., Ramanamanjato, J.-B. et al. 2005. An intersite comparison of fruit characteristics in Madagascar: Evidence for selection pressure through abiotic constraints rather than through co-evolution. In: Tropical Fruits and Frugivores. J. L. Dew and J. P. Boubli (eds.), pp 93-119. Springer, Netherlands.

Cain, M. L., Milligan, B. G. and Strand, A. E. 2000. Long-distance seed dispersal in plant populations. American Journal of Botany 87, 9 : 1217-1227

Callmander, M. W., Phillipson, P. B., Schatz, G. E., Andriambololonera, S., Rabarimanarivo, M., et al. 2011. The endemic and non-endemic vascuIar flora of Madagascar updated. Plant Ecology and Evolution 144, 2: 121-125. (doi:10.5091/plecevo.2011.513)

Clark, C. J., Poulsen, J. R., Connor, E. F. and Parker, V. T. 2004. Fruiting trees as dispersal foci in a semi-deciduous tropical forest. Oecologia 139, 1: 66-75. (doi:10.1007/s00442-003-1483-1)

Connell, J. H. 1971. On the role of natural enemies in preventing competitive exclusion in some marine animals and in rain forest trees. In: Dynamics of Populations. P. J. Den Boer and G. Gradwell (eds.), pp 298-312. PUDOC, Wageningen.

Cordeiro, N. J. and Howe, H. F. 2003. Forest fragmentation severs mutualism between seed dispersers and an endemic African tree. Proceedings of the National Academy of Sciences 100, 24: 14052-14056. (doi:10.1073/ pnas.2331023100)

Crowley, B. E., Godfrey, L. R. and Irwin, M. T. 2011. A glance to the past: Subfossils, stable isotopes, seed dispersal, and lemur species loss in southern Madagascar. American Journal of Primatology 73, 1: 25-37. (doi:10.1002/ajp.20817)

Dausmann, K. H., Glos, J., Linsenmair, K. E. and Ganzhorn, J. U. 2008. Improved recruitment of a lemur-dispersed tree in Malagasy dry forests after the demise of vertebrates in forest fragments. Oecologia 157, 2: 307-316. (doi:10.1007/s00442-008-1070-6)

del Hoyo, J., Elliott, A., Sargatal, J. and Cabot, J. 1992. Handbook of the Birds of the World. Lynx Edicions, Barcelona.

Dew, J. L. and Wright, P. 1998. Frugivory and seed dispersal by four species of primates in Madagascar's eastern rain forest. Biotropica 30, 3 : 425-437. (doi:10.1111/j.1744-7429.1998.tb00076.x)

Dewar, R. E. and Richard, A. F. 2012. Madagascar: A history of arrivals, what happened, and will happen next? Annual Review of Anthropology 41: 495-517. (doi:10.1146/annurev-anthro-092611-145758)

Dunham, A. E., Erhart, E. M., Overdorff, D. J. and Wright, P. C. 2008. Evaluating effects of deforestation, hunting, and El Niño events on a threatened lemur. Biological Conservation 141, 1: 287-297. (doi:10.1016/j.biocon.2007.10.006)

Dunham, A. E., Erhart, E. M. and Wright, P. C. 2011. Global climate cycles and cyclones: consequences for rainfall patterns and lemur reproduction in southeastern Madagascar. Global Change Biology 17, 1: 219-227. (doi:10.1111/j.1365-2486.2010.02205.x)

Farwig, N. and Berens, D. G. 2012. Imagine a world without seed dispersers: A review of threats, consequences and future directions. Basic and Applied Ecology 13, 2: 109-115. (doi:10.1016/j.baae.2012.02.006)

Fleming, T. H. 1979. Do tropical frugivores compete for food? American Zoologist 19, 4: 1157-1172. (doi:10.1093/icb/19.4.1157)

Forget, P. M. and Cuijpers, L. 2008. Survival and scatterhoarding of frugivores-dispersed seeds as a function of forest disturbance. Biotropica 40, 3: 380-385. (doi:10.1111/j.1744-7429.2007.00358.x)

Ganzhorn, J. U., Fietz, J., Rakotovao, E., Schwab, D. and Zinner, D. 1999. Lemurs and the regeneration of dry deciduous forest in Madagascar. Conservation Biology 13, 4: 794-804. (doi:10.1046/j.15231739.1999.98245.x)

Ganzhorn, J. U., Lowry II, P. P., Schatz, G. E. and Sommer, S. 2001. The biodiversity of Madagascar: One of the world's hottest hotspots on its way out. Oryx 35, 4: 346-348. (doi:10.1046/j.1365-3008.2001.00201.x) 
Godfrey, L. R., Jungers, W. L., Reed, K. E., Simons, E. L. and Chatrath, P. S. 1997. Subfossil lemurs: inferences about past and present primate communities in Madagascar. In: Natural Change and Human Impact in Madagascar. S. M. Goodman and B. D. Patterson (eds.), pp 218-256. Smithsonian Institution Press, Washington DC.

Goodman, S. M. and Sterling, E. J. 1996. The utilization of Canarium (Burseraceae) seeds by vertebrates in the Reserve Naturelle Integrale d'Andringitra, Madagascar. Fieldiana Zoology 85: 83-89.

Goodman, S. M., Ganzhorn, J. U. and Wilmé, L. 1997. Observations at a Ficus tree in Malagasy humid forest. Biotropica 29, 4: 480-488. (doi:10.1111/j.1744-7429.1997.tb00042.x)

Harper, G. J., Steininger, M. K., Tucker, C. J., Juhn, D. and Hawkins, F. 2007. Fifty years of deforestation and forest fragmentation in Madagascar. Environmental Conservation 34, 4: 325-333. (doi:10.1017/ S0376892907004262)

Hawkins, A. F. A. and Goodman, S. M. 2003. Introduction to the birds. In: The Natural History of Madagascar. S. M. Goodman and J. P. Benstead (eds.), pp 1019-1044. The University of Chicago Press, Chicago.

Herrera, C. M. 2002. Seed dispersal by vertebrates. In: Plant-Animal Interactions: an Evolutionary Approach. C.M. Herrera and O. Pellmyr (eds.), pp 185-208. Blackwell Science Ltd, Nashville, Tennessee.

Hnatiuk, S. H. 1978. Plant dispersal by the Aldabran giant tortoise, Geochelone gigantea (Schweigger). Oecologia 36, 3: 345-350. (doi:10.1007/BF00348060)

Holloway, L. 2000. Catalyzing rainforest restoration in Madagascar. In: Diversité et Endémisme à Madagascar. W. R. Lourenço and S. M. Goodman (eds.), pp 115-124 Mémoires de la Societé de Biogéographie Paris.

Howe, H. F. and Smallwood, J. 1982. Ecology of seed dispersal. Annual Review of Ecology and Systematics 13: 201-228.

Hubbell, S. P. 1979. Tree dispersion, abundance, and diversity in a tropical dry forest. Science 203, 4387: 1299-1309. (doi:10.1126/science.203.4387.1299)

Ibáñez, I., Clark, J. S., Dietze, M. C., Feeley, K., Hersh, M., et al. 2006. Predicting biodiversity change: outside the climate envelope, beyond the species-area curve. Ecology 87, 8: 1896-1906. (doi:10.1890/00129658(2006)87[1896:PBCOTC]2.0.C0;2)

Jansen, P. A., Hirsch, B. T., Emsens, W.-J., Zamora-Gutierrez, V., Wikelski, M. and Kays, R. 2012. Thieving rodents as substitute dispersers of megafaunal seeds. Proceedings of the National Academy of Sciences 109, 31: 12610-12615. (doi:10.1073/pnas.1205184109)

Janzen, D. H. 1970. Herbivores and the number of tree species in tropical forests. The American Naturalist 104, 940: 501-528.

Jordano, P., Forget, P.-M., Lambert, J. E., Böhning-Gaese, K., Traveset, A. and Wright, S. J. 2011. Frugivores and seed dispersal: mechanisms and consequences for biodiversity of a key ecological interaction. Biology Letters 7, 3: 321-323. (doi:10.1098/rsbl.2010.0986)

Kissling, W. D., Sekercioglu, C. H. and Jetz, W. 2012. Bird dietary guild richness across latitudes, environments and biogeographic regions. Global Ecology and Biogeography 21, 3: 328-340. (doi:10.1111/j.14668238.2011.00679.X)

Lahann, P. 2007. Feeding ecology and seed dispersal of sympatric cheirogaleid lemurs (Microcebus murinus, Cheirogaleus medius, Cheirogaleus major) in the littoral rainforest of south east Madagascar. Journal of Zoology 271, 1: 88-98. (doi:10.1111/j.14697998.2006.00222.x)

Langrand, O. 1990. Guide to the Birds of Madagascar. Yale University Press, New Haven.

Lomáscolo, S. B. and Schaefer, H. M. 2010. Signal convergence in fruits: a result of selection by frugivores? Journal of Evolutionary Biology 23, 3 614-624. (doi:10.1111/j.1420-9101.2010.01931.x)

Lomáscolo, S. B., Levey, D. J., Kimball, R. T., Bolker, B. M. and H. T. Alborn. 2010. Dispersers shape fruit diversity in Ficus (Moraceae). Proceedings of the National Academy of Sciences 107, 33: 14668-14672. (doi:10.1073/pnas.1008773107)

Long, E. and Racey, P. A. 2007. An exotic plantation crop as a keystone resource for an endemic megachiropteran, Pteropus rufus, in Madagascar. Journal of Tropical Ecology 23, 4: 397-407. (doi:10.1017/ S0266467407004178)
Martinez, B. T. and Razafindratsima, O. H. 2014. Frugivory and seed dispersal of the red-ruffed lemur (Varecia rubra) at a forest restoration site in Masoala National Park, Madagascar. Folia Primatologica 85, 4: 228-243. (doi:10.1159/000363408)

Mertl-Millhollen, A. S., Blumenfeld-Jones, K., Raharison, S. M., Tsaramanana, D. R. and Rasamimanana, H. 2011. Tamarind tree seed dispersal by ring-tailed lemurs. Primates 52, 4: 391-396. (doi:10.1007/s10329-0110253-7)

Midgley, J. J. and Illing, N. 2009. Were Malagasy Uncarina fruits dispersed by the extinct elephant bird? South African Journal of Science 105, 11-12: 467-469.

Moses, K. L. and Semple S. 2011. Primary seed dispersal by the blackand-white ruffed lemur (Varecia variegata) in the Manombo forest, south-east Madagascar. Journal of Tropical Ecology 27, 5: 529-538. (doi:10.1017/S0266467411000198)

Muller-Landau, H. C. and Hardesty, B. D. 2005. Seed dispersal of woody plants in tropical forests: concepts, examples and future directions. In: Biotic Interactions in the Tropics: Their Role in the Maintenance of Species Diversity. D. F. R. P. Burslem, M. A. Pinard, and S. E. Hartley (eds.), pp 267-309. Cambridge University Press, New York.

Overdorff, D. J. and Strait, S. G. 1998. Seed handling by three prosimian primates in southeastern Madagascar: implications for seed dispersal. American Journal of Primatology 45, 1: 69-82. (doi:10.1002/(SICI)10982345(1998)45:1<69::AID-AJP6>3.0.CO;2-U)

Pedrono, M., Griffiths, O. L., Clausen, A., Smith, L. L., Griffiths, C. J., et al. 2013. Using a surviving lineage of Madagascar's vanished megafauna for ecological restoration. Biological Conservation 159: 501-506. (doi:10.1016/j.biocon.2012.11.027)

Picot, M., Jenkins, R. K. B., Ramilijaona, O., Racey, P. A. and Carrière, S. M. 2007. The feeding ecology of Eidolon dupreanum (Pteropodidae) in eastern Madagascar. African Journal of Ecology 45, 4: 645-650. (doi:10.1111/j.1365-2028.2007.00788.x)

Rakotomanana, H., Hino, T., Kanzaki, M. and Morioka, H. 2003. The role of the Velvet Asity Philepitta castanea in regeneration of understory shrubs in Madagascan rainforest. Ornithological Science 2, 1: 49-58. (doi:10.2326/osj.2.49)

Ralisoamalala, R. C. 1996. Rôle de Eulemur fulvus rufus (Audeberg, 1799) et de Propithecus verreauxi verreauxi (A. Grandidier 1867) dans la dissémination des graines. In: Ecology and Economy of a Tropical Dry Forest in Madagascar. J. U. Ganzhorn and J.-P. Sorg (eds.), pp 285-293.Primate Report. Goltze, Göttingen, Germany.

Ratrimomanarivo, F. H. 2007. Diet of Eidolon dupreanum (Chiroptera: Pteropodidae) in the anthropized highlands of central Madagascar. Revue d'Ecologie, la Terre et la Vie 62, 2-3: 229-244.

Ratsimbazafy, J. H., Arrigo-Nelson, S. J., Dollar, L., Holmes, C. M., Irwin, M. T., et al. 2013. Conservation of Malagasy Prosimians: A View from the Great Red Island. In: Leaping Ahead. J. Masters, M. Gamba and F. Génin (eds.), pp 387-396. Springer, New York.

Razafindratsima, O. H, and Dunham, A. E. 2014. Assessing the impacts of nonrandom seed dispersal by multiple frugivore patterns on plant recruitment. Ecology. (doi:10.1890/14-0684.1)

Razafindratsima, O. H. and Martinez, B. T. 2012. Seed dispersal by red-ruffed lemurs: seed size, viablity, and beneficial effect on seedling growth. Ecotropica 18:15-26.

Razafindratsima, O. H. and Razafimahatratra, E. 2010. Effect of red ruffed lemur gut passage on the germination of native rainforest plant species. Lemur News 15: 39-42.

Razafindratsima, O. H., Jones, T. A. and Dunham, A. E. 2014. Patterns of movement and seed dispersal by three lemur species. American Journal of Primatology 76, 1: 84-96. (doi:10.1002/ajp.22199)

Sato, H. 2012. Frugivory and seed dispersal by brown lemurs in a Malagasy tropical dry forest. Biotropica 44, 4: 479-488. (doi:10.1111/j.17447429.2011.00838.x)

Sato, H. 2013. Seasonal fruiting and seed dispersal by the brown lemur in a tropical dry forest, north-western Madagascar. Journal of Tropical Ecology 29, 1: 61-69. (doi:10.1017/S0266467413000011)

Schaefer, H. M., Schaefer, V. and Levey, D. J. 2004. How plant-animal interactions signal new insights in communication. Trends in Ecology \& Evolution 19. 11: 577-584. (doi:10.1016/j.tree.2004.08.003) 
Scharfe, F. and W. Schlund. 1996. Seed removal by lemurs in a dry deciduous forest of western Madagascar. Primate Report 46, 1: 295-304.

Schupp, E. W., Milleron, T. and Russo, S. E. 2002. Dissemination limitation and the origin and maintenance of species-rich tropical forests. In: Seed Dispersal and Frugivory: Ecology, Evolution, and Conservation. D. J. Levey, W. R. Silva, and M. Galetti (eds.), pp 19-33. CABI, New York.

Schupp, E. W., Jordano, P. and Gómez, J. M. 2010. Seed dispersal effectiveness revisited: a conceptual review. New Phytologist 188, 2: 333-353. (doi:10.1111/j.1469-8137.2010.03402.x)

Schwitzer, C., Mittermeier, R., Davies, N., Johnson, S. E., Ratsimbazafy, J. et al. 2013. Lemurs of Madagascar: A Strategy for their Conservation 2013-2016. IUCN SSC Primate Specialist Group, Bristol Conservation and Scienec Foundation, and Conservation International, Bristol, UK. Available at <https://portals.iucn.org/library/node/10414>

Shapcott, A., Rakotoarinivo, M., Smith, R. J., Lysakova, G., Fay, M. F. and Dransfield, J. 2007. Can we bring Madagascar's critically endangered palms back from the brink? Genetics, ecology and conservation of the critically endangered palm Beccariophoenix madagascariensis. Botanical Journal of the Linnean Society 154, 4: 589-608. (doi:10.1111/ j.1095-8339.2007.00676.x)

Spehn, S. E. and Ganzhorn, J. U. 2000. Influence of seed dispersal by brown lemurs on removal rates of three Grewia species (Tiliaceae) in the dry deciduous forest of Madagascar. Ecotropica 6, 1: 13-21.

Terborgh, J., Pitman, N., Silman, M., Schichter, H. and Nunez, P. V. 2002 Maintenance of tree diversity in tropical forests. In: Seed Dispersal and Frugivory: Ecology, Evolution, and Conservation. D. J. Levey, W. R. Silva, and M. Galetti (eds.), pp 1-17. CABI, New York.

Traveset, A., Robertson, A. W. and Rodríguez-Pérez, J. 2007. A review on the role of endozoochory on seed germination. In: Seed Dispersal: Theory and its Application in a Changing World. A. J. Dennis, E. W. Schupp, R. A. Green, and D. A. Westcott (eds.), pp. 78-103. CABI Publishing, Wallingford, UK.

Valenta, K., Burke, R. J., Styler, S. A., Jackson, D. A., Melin, A. D. andLehman, S. M. 2013. Colour and odour drive fruit selection and seed dispersal by mouse lemurs. Scientific Reports 3: Article number 2424. (doi:10.1038/srep02424)

Valido, A. and Olesen, J. M. 2007. The importance of lizards as frugivores and seed dispersers. In: Seed Dispersal: Theory and its Application in a Changing World. A. J. Dennis, E. W. Schupp, R. A. Green, and D. A. Westcott (eds.), pp. 124-147. CABI Publishing, Wallingford, UK.

Vander Wall, S. B., Kuhn, K. M., and Beck, M. J. 2005. Seed removal, seed predation, and secondary dispersal. Ecology 86: 801-806. (doi:10.1890/040847)

Voigt, F. A., Burkhardt, J. F., Verhaagh, M. and Böhning-Gaese, K. 2002. Regional differences in ant community structure and consequences for secondary dispersal of Commiphora seeds. Ecotropica 8: 59-66.

Voigt, F. A., Bleher, B., Fietz, J., Ganzhorn, J. U., Schwab, D. and BöhningGaese, K. 2004. A comparison of morphological and chemical fruit traits between two sites with different frugivore assemblages. Oecologia 141, 1: 94-104. (doi:10.1007/s00442-004-1654-8)

Voigt, F. A., Arafeh, R., Farwig, N., Griebeler, E. M. and Böhning Gaese, K. 2009. Linking seed dispersal and genetic structure of trees: a biogeographical approach. Journal of Biogeography 36, 2: 242-254. (doi:10.1111/j.1365-2699.2008.02002.x)

Walker, B. 1995. Conserving biological diversity through ecosystem resilience. Conservation Biology 9, 4: 747-752. (doi:10.1046/j.15231739.1995.09040747.x)

Wang, B. C. and Smith, T. B. 2002. Closing the seed dispersal loop. Trends in Ecology \& Evolution 17, 8: 379-386. (doi:10.1016/S0169-5347(02)025417)

Watson, J. E. M., Joseph, L. N. and Fuller, R. A. 2010. Mining and conservation: Implications for Madagascar's littoral forests. Conservation Letters 3: 286-287. (doi:10.1111/j.1755-263X.2010.00124.X)

Wright, P. C., Tecot, S. R., Erhart, E. M., Baden, A. L., King, S. J. and Grassi, C. 2011. Frugivory in four sympatric lemurs: Implications for the future of Madagascar's forests. American Journal of Primatology 73, 6: 585-602. (doi:10.1002/ajp.20936)

\section{SUPPLEMENTARY MATERIAL.}

AVAILABLE ONLINE ONLY.

TABLE S1. List of known extant vertebrate species in Madagascar with fruits as an important diet item, and their potential roles as primary seed dispersers or predators. 